\title{
Effect of Pilates exercise on the level of fatigue, cognition and knee proprioception in the elderly population of $60-80$ years
}

\section{Shradha Santosh Shah ${ }^{* 1}$, Sandhya Wasnik ${ }^{2}$.}

${ }^{* 1}$ MPT, Neurophysiotherapy, All India Institute of Physical Medicine and Rehabilitation, Mumbai, Maharashtra 400034, India.

2 Professor, All India Institute of Physical Medicine and Rehabilitation, Mumbai, Maharashtra 400034, India.

\section{ABSTRACT}

Aim: To evaluate the effect of Pilates exercise on the level of fatigue, cognition and knee proprioception in elderly population (60-80 years).

Study design: experimental study; randomized control trial.

Method: 40 subjects both male and female of age ranging from $60-80$ years $(66.578 \pm 4.857$ in group A and $69.4 \pm 5.442$ in group B) were assigned in to two groups. The objective of the study was explained, and the subjects were screened based on the inclusion and exclusion criteria. Pre-interventional and post-interventional data analysis was done for FSS, 6MWT, MoCA and KJPS error angle. Group A (Experimental group) received Pilates exercise. Group B (control group) received aerobic and strengthening exercises. Both the groups underwent exercises 3 times a week on alternate days for 6 weeks. Duration of exercise for both groups was 45-60 minutes.

Results: Both the groups showed clinically and statistically significant improvement in FSS ( $p<0.0001$ in both groups) 6MWT ( $<<0.0001$ in both groups), MoCA ( $<<0.001$ in both groups) and KJPS scores ( $<<0.0002$ in group $A$ and $p<0.0001$ in group $B$ ) at the end of 6 weeks of treatment. There was no significant difference between the groups for FSS $(p=0.7226), 6 M W T(p=0.813)$, MoCA $(p=0.416)$ and KJPS $(p=0.6213)$.

Conclusion: A significant improvement were observed in both the groups; which concluded that both the groups are equally effective in improvement of FSS, 6MWT, MoCA and KJPS scores.

KEY WORDS: Pilates exercise, elderly population, fatigue, cognition, knee proprioception.

Address for correspondence: Dr. Shradha Santosh Shah, PT., MPT, Neurophysiotherapy, All India Institute of Physical Medicine and Rehabilitation, Mumbai, Maharashtra 400034, India.

E-Mail: shradhashah76@gmail.com

Quick Response code

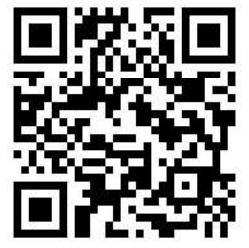

DOI: $10.16965 /$ ijpr.2020.188

International Journal of Physiotherapy and Research ISSN (E) 2321-1822 | ISSN (P) 2321-8975

https://www.ijmhr.org/ijpr.html

DOI-Prefix: https://dx.doi.org/10.16965/ijpr

Article Information

Received: 08 Dec 2020

Peer Review: 08 Dec 2020

Revised: 31 Dec 2020 (c) $\mathrm{Br}+\mathrm{Mr}-\mathrm{si}$

\begin{tabular}{|ll|}
\hline \multicolumn{2}{|c|}{ Article Information } \\
\hline Received: 08 Dec 2020 & Accepted: 28 Jan 2021 \\
Peer Review: 08 Dec 2020 & Published (O): 11 Mar 2021 \\
Revised: 31 Dec 2020 & Published (P): 11 Apr 2021
\end{tabular}

\section{INTRODUCTION}

Aging refers to the inevitable process which leads to progressive structural and functional loss in the body. There occurs group of developmental changes which leads to fatigability in the elderly people [1,2]. There is correlation of fatigue with altered joint position sense leading to balance deficits and on cognitive function which interferes with executive function of motor performance [3]. Muscle fatigue adversely affects joint proprioception and impairs neuromuscular component in lower extremities. Fatigue usually affects the knee joint proprioception as it is 
most sensitive joint for fatigue and aging commonly leads to decrease in knee joint proprioception [3].

Pilates improves muscular control of deeper abdominal muscles which helps to restore balance by adjusting the centre of the body $[4,5]$. It works on the 6 principles as followscantering, concentration, control, precision, breath, flow. The way Pilates exercise are performed are of great importance than number of repetitions i.e. the quality is superior than quantity. Pilates not only exercises the body but it also simultaneously exercises the mind [6]. Pilates is also known as 'contrology' [7].

Studies have been done demonstrating the effect of Pilates exercise on the level of fatigue in multiple sclerosis, breast cancer and normal healthy adults. Effects have also been documented on the cognitive level in multiple sclerosis and knee proprioception in orthopedic conditions and young adults. Knee is the most commonly affected joint in terms of proprioceptive decline and hence in this study also knee joint proprioception is taken into consideration [3].

Pilates exercises on static and dynamic balance, gait parameters in older adults and stroke have also been studied and proven to be beneficial. A systematic review done on the effect of Pilates method in elderly revealed that none of the study was addressing the level of fatigue [1]. So, there is lack of evidence of Pilates exercise on the level of fatigue, cognition and knee proprioception in the elderly population. Hence the need arises to assess the effect of Pilates exercise on the level of fatigue, cognition and knee propriocpetion in the elderly population.

The aim of the present study is to evaluate the effect of Pilates exercise on the level of fatigue, cognition and knee proprioception in elderly population (60-80 years).

\section{MATERIALS AND METHODS}

Approval from the ethics committee and synopsis committee was taken, prior to initiation of the study. This study was conducted among the elderly population age ranging from $60-80$ years. Data was collected from the tertiary health care centre.
The purpose of the study was explained and the subjects were screened based on inclusion and exclusion criteria and were allocated in to two groups i.e. group $A$ (experimental) and group $B$ (control). Written informed consent were taken from the subjects after their inclusion. Pre-interventional fatigue assessment was done by FSS, 6MWT, assessment of cognition was done by MoCA score and knee proprioception assessment was done by recording KJPS error angle by universal goniometer. After 6 weeks of treatment for both the groups post interventional data was analysed.

Inclusion criteria were elderly population of $60-80$ years, FSS $>36, \mathrm{MoCA}=17-25$ and exclusion criteria were any existing musculoskeletal conditions (knee pain, back pain, hernia, diastesis recti), neurological deficits (stroke, Parkinson's disease, and neuropathies), severe cognitive impairments, any cardiovascular disease (acute myocardial infarction, acute heart failure, and uncontrolled hypertension), unstable chronic diseases (diabetes, malignancy), any surgical intervention past six months, unwillingness to continue participation in the study.

Statistical Analysis: Analysis for this data was done by using software Graphpad prism 8 . The results were considered significant at ' $p$ ' value $=<0.05$ and confidence interval $(\mathrm{Cl})$ at $95 \%$. The data passed normality test by Shapiro Wilk test. Hence, parametric test was used for analysis. Paired and Unpaired ' $t$ ' test was used for intra and inter-group analysis respectively.

Procedure: Assessment of fatigue was evaluated by asking the patient to rate the fatigue severity scale from 1 to 7 which indicates strongly disagree to strongly agree. FSS score $\geq 4$ be interpreted as indicative of fatigue. The total score of $>36$ is indicative of fatigue [7]. Exercise capacity was assessed using Six-Minute Walk Test (6MWT) which is an objective measure and is representative of a person's ability because the test intensity is self-selected $[8,9]$.

Knee joint proprioception sense (KJPS) was measured by universal goniometer. The goniometer was attached to the tested leg secured by straps. Fulcrum coincided with the lateral 


\begin{tabular}{|c|c|c|c|c|c|}
\hline Week 1 & Week 2 & Week 3 & Week 4 & Week 5 & Week 6 \\
\hline \multirow[t]{8}{*}{ Core activation } & $\begin{array}{l}\text { One leg lifts: supine } \times 5 \\
\text { reps, } 1 \text { set }\end{array}$ & $\begin{array}{l}\text { One leg lifts: } \\
\text { supine } \times 7 \text { reps, } 1 \\
\text { set }\end{array}$ & $\begin{array}{l}\text { One leg lifts: supine } x \\
7 \text { reps, } 2 \text { sets }\end{array}$ & $\begin{array}{l}\text { One leg lifts: supine } \times 10 \\
\text { reps, } 2 \text { sets }\end{array}$ & $\begin{array}{l}\text { One leg lifts: supine } \times 10 \\
\text { reps, } 3 \text { sets }\end{array}$ \\
\hline & Sliding leg $\times 5$ reps, 1 set & $\begin{array}{l}\text { Sliding leg } \times 7 \text { reps, } \\
1 \text { set }\end{array}$ & $\begin{array}{l}\text { Sliding leg } \times 7 \text { reps, } 2 \\
\text { sets }\end{array}$ & $\begin{array}{l}\text { Sliding leg } \times 10 \text { reps, } 2 \\
\text { sets }\end{array}$ & Sliding leg $\times 10$ reps, 3 sets \\
\hline & $\begin{array}{l}\text { Hundred: basic } \times 5 \text { reps, } 1 \\
\text { set }\end{array}$ & $\begin{array}{l}\text { Hundred: basic } \times 7 \\
\text { reps, } 1 \text { set }\end{array}$ & $\begin{array}{l}\text { Hundred: basic } \times 7 \\
\text { reps, } 2 \text { sets }\end{array}$ & $\begin{array}{l}\text { Hundred: basic } \times 10 \\
\text { reps, } 2 \text { sets }\end{array}$ & $\begin{array}{l}\text { Hundred: basic } \times 10 \text { reps, } 3 \\
\text { sets }\end{array}$ \\
\hline & $\begin{array}{l}\text { Single leg stretch at } 90^{\circ} \times 5 \\
\text { reps, } 1 \text { set }\end{array}$ & $\begin{array}{l}\text { Single leg stretch } \\
\text { at } 90^{\circ} \times 7 \text { reps, } 1 \\
\text { set }\end{array}$ & $\begin{array}{l}\text { Single leg stretch at } \\
60^{\circ} \times 5 \text { reps, } 1 \text { set }\end{array}$ & $\begin{array}{l}\text { Single leg stretch at } 60^{\circ} \\
\times 7 \text { reps, } 2 \text { sets }\end{array}$ & $\begin{array}{l}\text { Single leg stretch at } 60^{\circ} \times \\
10 \text { reps, } 2 \text { sets }\end{array}$ \\
\hline & $\begin{array}{l}\text { Double leg stretch at } 90^{\circ} \times \\
5 \text { reps, } 1 \text { set }\end{array}$ & $\begin{array}{l}\text { Double leg stretch } \\
\text { at } 90^{\circ} \times 7 \text { reps, } 1 \\
\text { set }\end{array}$ & $\begin{array}{l}\text { Double leg stretch at } \\
60^{\circ} \times 5 \text { reps, } 1 \text { set }\end{array}$ & $\begin{array}{l}\text { Double leg stretch at } 60^{\circ} \\
\times 7 \text { reps, } 2 \text { sets }\end{array}$ & $\begin{array}{l}\text { Double leg stretch at } 60^{\circ} \times \\
10 \text { reps, } 2 \text { sets }\end{array}$ \\
\hline & $\begin{array}{l}\text { Single leg circles } \times 5 \text { reps, } 1 \\
\text { set }\end{array}$ & $\begin{array}{l}\text { Single leg circles } x \\
7 \text { reps, } 1 \text { set }\end{array}$ & $\begin{array}{l}\text { Single leg circles } \times 7 \\
\text { reps, } 2 \text { sets }\end{array}$ & $\begin{array}{l}\text { Single leg circles } \times 10 \\
\text { reps, } 2 \text { sets }\end{array}$ & $\begin{array}{l}\text { Single leg circles } \times 10 \text { reps, } \\
3 \text { sets }\end{array}$ \\
\hline & Side to side $\times 5$ reps, 1 set & $\begin{array}{l}\text { Side to side } \times 7 \\
\text { reps, } 1 \text { set }\end{array}$ & $\begin{array}{l}\text { Side to side } \times 7 \text { reps, } \\
2 \text { sets }\end{array}$ & $\begin{array}{l}\text { Side to side } \times 7 \text { reps, } 2 \\
\text { sets }\end{array}$ & $\begin{array}{l}\text { Ankle weights- outer thigh, } \\
\text { inner thigh, back of thigh } \times \\
10 \text { reps, } 3 \text { sets }\end{array}$ \\
\hline & $\begin{array}{l}\text { Stomach stretch } \times 5 \text { reps, } 1 \\
\text { set }\end{array}$ & $\begin{array}{l}\text { Stomach stretch } \times 7 \\
\text { reps, } 1 \text { set }\end{array}$ & $\begin{array}{l}\text { Stomach stretch } \times 7 \\
\text { reps, } 2 \text { sets }\end{array}$ & $\begin{array}{l}\text { Stomach stretch } \times 7 \\
\text { reps, } 2 \text { sets }\end{array}$ & $\begin{array}{l}\text { Arm weights opening arms, } \\
\text { alternating arms, } \times 10 \\
\text { reps, } 3 \text { sets }\end{array}$ \\
\hline
\end{tabular}

joint line of knee, while one arm of the goniometer was aligned parallel to the line joining the greater trochanter and fulcrum and the other arm to the leg i.e., along the line joining fulcrum and lateral malleolus. The subject was in high sitting position with thigh fully supported on the plinth. Demonstration of the test with eyes open was done for better understanding of the test. With the subject's eye closed, therapist passively moved the limb to reach the knee joint to a particular test angle. Subject was blind folded to avoid any visual cues. The examiner passively flexed the knee joint from the extended position to the target angle of $30^{\circ}$ at a very low speed. Subject identified the test position. Five practice sessions were given and then the subject was asked to reproduce the target position actively using the same limb. Response positions were measured as the angle at which the subject stopped. Three consecutive response angles were noted and the best of the three values was noted [10].

In experimental group, Core activation technique was taught to the subjects with the help of core stabilizer unit prior to beginning of Pilates exercises. All the exercises in the experimental group were performed alternately with bilateral lower extremity one after the other. Pilates exercises were- core activation technique, one leg lifts, sliding leg, hundred: basic, single leg stretch, double leg stretch, single leg circles, stomach stretch, side to side, ankle weights: outer thigh, inner thigh, back of thigh and alternating arm opening [6]. In control group, According to ACSM guidelines [11], Cycling was given as an aerobic exercise and adjunct to this muscle strengthening exercises (upper extremity, lower extremity and trunk strengthening) were given. Moderate intensity was selected (i.e., 5-6 on a scale of 0-10 for level of physical exertion). Cycling exercises were performed for 10 minutes at $1^{\text {st }}$ and $2^{\text {nd }}$ week. At $3^{\text {rd }}$ and $4^{\text {th }}$ week, cycling was performed for 20 minutes; whereas for $5^{\text {th }}$ and $6^{\text {th }}$ week duration of exercise was for 30 minutes. Strengthening exercises were given by half kg weight cuff. Shoulder, elbow, hip, knee, abdominals, back extensor muscle strengthening were performed for 10-15 repetitions. In both the groups, exercises were given thrice a week for 6 weeks. Duration of one session was 45-60 minutes.

\section{RESULTS}

Total 40 eligible subjects were recruited in the study, however one subject from experimental group dropped out at the $4^{\text {th }}$ week of Pilates training. Therefore, data was analyzed by taking 19 subjects in experimental and 20 
in control group. Anthropometric data of subjects at baseline shows non significant difference between the groups (table 1). After Pilates and conventional exercises, the mean values of FSS, 6MWT, MoCA and KJPS error angle shows statistically significant differences post intervention in the experimental and control group respectively (table $2 \& 3$ ). Whereas comparison of mean difference values of FSS, 6MWT, MoCA and KJPS error angle between the groups showed non significant results (table 4).

Table 1: Anthropometric data of subjects at baseline.

\begin{tabular}{|cccccc|}
\hline Demographic data & Mean (SD) & ' $\mathbf{t}$ ' value & ' $\mathbf{p}$ ' value & Significance \\
\hline \multicolumn{7}{c}{ Group A } & Group B \\
\hline Age & $66.578 \pm 4.857$ & $69.4 \pm 5.442$ & 1.705 & 0.096 & NS \\
\hline BMI & $25.808 \pm 3.494$ & $27.114 \pm 3.707$ & 1.13 & 0.265 & NS \\
\hline
\end{tabular}

Table 1 shows the age \& BMI wise distribution of group A and group B which shows non significant difference between the groups.

Table 2: Comparison of mean values of FSS, 6MWT, MoCA and KJPS error angle pre and post values in group A.

\begin{tabular}{|cccccc|}
\hline Outcomes & Mean (SD) & & ' $\mathbf{t}$ 'value & ' $\mathbf{p}$ ' value & Significance \\
\hline \multicolumn{7}{|c|}{ Pre } & Post & & & \\
\hline 6MS & $43.842 \pm 4.072$ & $24.736 \pm 8.305$ & 10.82 & $<0.0001$ & Yes \\
\hline MoCA & $345.263 \pm 31.290$ & $385.526 \pm 32.740$ & 9.047 & $<0.0001$ & Yes \\
\hline KJPS error angle & $5.105 \pm 3.725$ & $1.368 \pm 2.139$ & 5.004 & $<0.0001$ & Yes \\
\hline
\end{tabular}

The above table shows that after Pilates training, the mean value shows statistically significant differences post intervention in the experimental group.

Table 3: Comparison of mean values of FSS, 6MWT, MoCA and KJPS error angle pre and post values in group B.

\begin{tabular}{|cccccc|}
\hline Outcomes & Mean (SD) & & ' $\mathbf{t}$ ' value & ' $\mathbf{p}$ ' value & Significance \\
\hline & Pre & Post & & & \\
\hline FSS & $44.65 \pm 4.258$ & $26.35 \pm 6.651$ & 11.92 & $<0.0001$ & Yes \\
\hline 6MWT & $353.25 \pm 35.919$ & $392 \pm 35.555$ & 8.556 & $<0.0001$ & Yes \\
\hline MoCA & $25.45 \pm 2.163$ & $26.45 \pm 1.468$ & 3.823 & $<0.0011$ & Yes \\
\hline KJPS error angle & $4.35 \pm 2.134$ & $1.35 \pm 2.412$ & 5.576 & $<0.0001$ & Yes \\
\hline
\end{tabular}

The above table shows that after aerobic and strength training, the mean value shows statistically significant difference in FSS values post intervention in the control group.

Table 4: Comparison of mean difference values of FSS, 6MWT, MoCA and KJPS error angle between group A and group $B$.

\begin{tabular}{|cccccc|}
\hline Outcomes & Mean (SD) & & ' $t$ ' value & ' $\mathbf{p}$ ' value & Significance \\
\hline & Group A & Group B & & & \\
\hline 6MWT & $40.26 \pm 19.40$ & $38.75 \pm 20.25$ & 0.238 & 0.8132 & NS \\
\hline MoCA & $1.368 \pm 1.606$ & $1.00 \pm 1.17$ & 0.822 & 0.4163 & NS \\
\hline KJPS error angle & $3.737 \pm 3.229$ & $3.00 \pm 2.40$ & 0.8109 & 0.4226 & NS \\
\hline
\end{tabular}

The above table shows that after training, the mean values shows statistically non significant differences in FSS, 6MWT, MoCA and KJPS error angle values.

\section{DISCUSSION}

Reduction in fatigue levels can be attributed to centering principle of Pilates which increases body energy, sleep quality, releases negative thinking, improves blood flow to brain and hence muscle gets relaxed. Another mechanism may be due to control and precision principles, which by engaging the core and integrating upper and lower extremity strengthening may reduce fatigue. It had concluded that by improvements in the strength, fatigue can be reduced in the elderly population [12]. A study done by Melda Soysal Tomruk et.al, had concluded that Pilates exercise may reduce fatigue by improving balance control, cognitive and proprioceptive 
function as fatigue is correlated to cognition and proprioception [14].

Improvements in the cognition by Pilates exercise can be due to concentration and precision principles of Pilates. By performing exercises, brain controls the body movements performed during exercises which leads to increased attention and concentration, memory speed processing increases which ultimately leads to improvements in cognitive functions. This exercise activates brain cells which in turn activates mind and can improve executive function of cognition $[12,15]$.

Pilates exercises may improve proprioception by mental effort i.e. while performing exercises it focuses on activating specific muscles at accurate speed, quality, precision and control of movement with specific joint awareness [10].

Aerobic exercises may reduce fatigue by increase in the blood supply to the working muscles. This could occur due to generalized vasoconstriction which allows blood to shift from non-working muscles, kidneys, liver, spleen and splanchic area to working muscles. It may also occur locally at peripheral level by reduction in resistance to working muscle arterial vascular bed through $\mathrm{Mg}^{2+}, \mathrm{Ca}^{2+}, \mathrm{ADP}$ and $\mathrm{PCO}_{2}$ independent of autonomic nervous system. Another mechanism is due to increase in stroke volume, heart rate and myocardial contractility which leads to increase in cardiac output and increase in blood flow to working muscles and provides additional oxygen to muscles [16].

Laitman et al have studied the effects of exercise on cognitive integrity of the aging brain. Aging leads to declines in neurovascular integrity and has found the correlation between neurovascular dysfunction and innate inflammation in the context of cognitive decline. The authors concluded that long term exercises have positive impact on neurovascular integrity and is correlated to improved behavioral outcomes, markers of neuroplasticity and reduced inflammation. This leads to improvements in cognitive functions [17].

A multiple number of studies had seen the effects of physical exercise on the knee joint position sense and had concluded tha $t$ regular physical exercises had improvements in the knee joint proprioception sense. Physical exercise induces morphological adaptations in the muscle spindle at the peripheral level rather than changing the number of mechanoreceptors.

At central level, there is improvement in proprioception sense by modulation of muscle spindle gain and the plastic changes in the central nervous system. During physical activity, there is increase in muscle spindle output through gamma route which facilitates the cortical projection of proprioception. Through improvements in muscle spindle output, plastic changes in the central nervous system include increase in the strength of synaptic connections and structural modifications in the organization and number of connection among neurons. Thus repetitive afferent inputs from mechanoreceptors modifies the cortical maps of the body overtime leading to increase in cortical representation of joints and hence enhanced joint proprioception $[10,18]$.

\section{CONCLUSION}

Pilates exercises are significantly effective on the level of fatigue, knee proprioception and cognition in the elderly population of $60-80$ years. Result of this study supports the importance of Pilates exercises in geriatric rehabilitation.

\section{Conflicts of interest: None}

\section{REFERENCES}

[1]. Engers PB, Rombaldi AJ, Portella EG, da Silva MC. The effects of the Pilates method in the elderly: a systematic review. Rev Bras Reumatol. 2016 Aug;56(4):352-65.

[2]. Shortz AE, Pickens A, Zheng Q, Mehta RK. The effect of cognitive fatigue on prefrontal cortex correlates of neuromuscular fatigue in older women. J NeuroEngineering Rehabil. 2015 Dec 21;12:115

[3]. Grobe S, Kakar RS, Smith ML, Mehta R, Baghurst T, Boolani A. Impact of cognitive fatigue on gait and sway among older adults: A literature review. Prev Med Rep. 2017 Feb 24;6:88-93.

[4]. Ribeiro F, Oliveira J. Aging effects on joint proprioception: the role of physical activity in proprioception preservation. Eur Rev Aging Phys Act. 2007 Oct 1;4(2):71-6. 
[5]. O'Sullivan SB.Physical Rehabilitation 6th edition.F.A. Davis Company.2014.

[6]. Menezes A.The complete guide to Joseph H Pilates' Techniques of Physical Conditioning with special help for back pain \& sports training. 2nd ed. Hunter House Publishers.2004.

[7]. Hassanpour-Dehkordi A, Jalali A. Effect of Progressive Muscle Relaxation on the Fatigue and Quality of Life Among Iranian Aging Persons. Acta Med Iran. 2016 Jul;54(7):430-6.

[8]. McGregor KM, Nocera JR, Sudhyadhom A, Patten C, Manini TM, Kleim JA, et al. Effects of aerobic fitness on aging-related changes of interhemispheric inhibition and motor performance. Front Aging Neurosci. 2013;5:66.

[9]. Guccione A. Geriatric Physical Therapy - 3rd Edition [Internet]. [cited 2019 Jun 28]. Available from: 978-0-323-02948-3.

[10]. Kaur R. comparision of pilates exercise and proprioceptive exercises on joint position sense in people with knee osteoarthritis. International Journal of Yoga, Physiotherapy and Physical Education. 2018 Jan;3(1):101-5.

[11].Potteiger J.A. ACSM's Introduction to Exercise Science. $3^{\text {rd }}$ edition. Wolters Kluwer Health, 2017.
[12]. Memmedova K. Impact of Pilates on Anxiety Attention, Motivation, Cognitive function and Achievement of Students: Structural Modeling. Procedia - Soc Behav Sci. 2015 May 13;186: 544-8.

[13]. Simoneau M, Bégin F, Teasdale N. The effects of moderate fatigue on dynamic balance control and attentional demands. J NeuroEngineering Rehabil. 2006 Sep 28;3:22.

[14]. Soysal Tomruk M, Uz MZ, Kara B, Ýdiman E. Effects of Pilates exercises on sensory interaction, postural control and fatigue in patients with multiple sclerosis. Mult Scler Relat Disord. 2016 May;7:70-3.

[15].Di Lorenzo CE. Pilates. Sports Health. 2011 Jul;3(4):352-61.

[16]. Kisner carolyn. Therapeutic Exercise/ : Foundations and Techniques, 6th Edition.F.A. Davis Company. 2017.

[17]. Laitman BM, John GR. Understanding How Exercise Promotes Cognitive Integrity in the Aging Brain. PLoS Biol. 2015;13(11):e1002300.

[18]. Ribeiro F, Oliveira J. Effect of physical exercise and age on knee joint position sense. Arch Gerontol Geriatr. 2010 Aug;51(1):64-7.

How to cite this article:

Shradha Santosh Shah, Sandhya Wasnik. Effect of Pilates exercise on the level of fatigue, cognition and knee proprioception in the elderly population of 60-80 years. Int J Physiother Res 2021;9(2):3774-3777. DOI: 10.16965/ ijpr.2020.188 